\title{
SEL BETA PANKREAS SINTESIS DAN SEKRESI INSULIN
}

\author{
Eka Banjarnahor \\ Sunny Wangko
}

\begin{abstract}
Bagian Anatomi-Histologi Fakultas Kedokteran Universitas Sam Ratulangi Manado
Email: www.ekabanjarnahor@yahoo.com
\end{abstract}

\begin{abstract}
Insulin synthesis and secretion are done by pancreatic beta cells. Preceding the insulin synthesis, there is a gen translation in chromosome 11 that produces insulin, packed in secretory granules. Insulin secretion is induced by the alteration of blood glucose levels, resulting in the occurence of intracellular reactions preceded by changes of ATP/ADP ratios that trigger the depolarisation of plasma membranes. Furthermore, extracellular $\mathrm{Ca}^{2+}$ ions move inward to beta cells to activate exocytosis. There are still many unknown problems so far in either the synthesis or secretion of insulin that cause unfulfilled insulin needs in the body.
\end{abstract}

Keywords: beta cells, insulin, synthesis, secretion

\begin{abstract}
Abstrak: Sintesis dan sekresi insulin dilakukan oleh sel beta pankreas. Sintesis insulin diawali oleh salinan gen pada kromosom 11, yang akan menghasilkan insulin, di kemas di dalam granul-granul sekretorik. Sekresi insulin diinduksi oleh perubahan kadar glukosa, yang berakibat terjadinya reaksi intrasel yang diikuti adanya perbedaan rasio ATP/ADP yang memicu reaksi depolarisasi membran plasma. Sebagai akibat lanjut $\mathrm{Ca}^{2+}$ ekstrasel akan masuk ke dalam sel beta yang berfungsi mengaktifkan eksositosis. Sampai saat ini masih banyak ditemui masalah baik dalam hal sintesis maupun sekresi insulin yang mengakibatkan kebutuhan insulin tubuh tidak terpenuhi.
\end{abstract}

Kata kunci: sel beta, insulin, sintesis, sekresi

Sangat mudah mengatakan: "kita adalah apa yang kita makan", tetapi pernyataan sederhana ini tidak dapat menjelaskan secara detail mengenai kompleksitas sinyal metabolik yang terjadi di dalam tubuh yang berfungsi menjaga homeostasis tubuh. Sampai saat ini ahli biologi molekular masih tetap meneliti untuk menemukan bagian-bagian dari setiap molekul sel yang terkait dengan penyakit yang serius. Salah satunya ialah sel beta pulau Langerhans pankreas yang memroduksi insulin.

Proses sintesis dan sekresi insulin ini terjadi tepatnya pada sel-sel beta pulaupulau Langerhans pankreas. Kedua proses ini melibatkan berbagai komponen yang mendukung perlangsungan proses-proses tersebut dengan hasil akhirnya insulin. Pada keadaan tertentu komponen-komponen yang berada dalam sel ini dapat mengalami disfungsi, yang akan mengganggu sintesis dan sekresi sehingga menimbulkan penyakit.

\section{GAMBARAN HISTOLOGIK PULAU LANGERHANS}

Pulau Langerhans merupakan mikroorgan endokrin multihormonal di pankreas. Pulau-pulau ini tampak sebagai kelompok bangunan bulat dengan sel-selnya terpendam di dalam jaringan eksokrin pankreas (Gambar 1).,3 Pulau Langerhans tidak dapat dilihat dengan mata telanjang 
tetapi jika diperfusi dengan larutan pewarna merah netral maka pulau- pulau akan terpulas selektif (Gambar 1), sehingga dapat dipelajari jumlah dan penyebarannya. Pulau-pulau ini tersebar merata namun agak lebih banyak pada bagian kauda. ${ }^{4}$

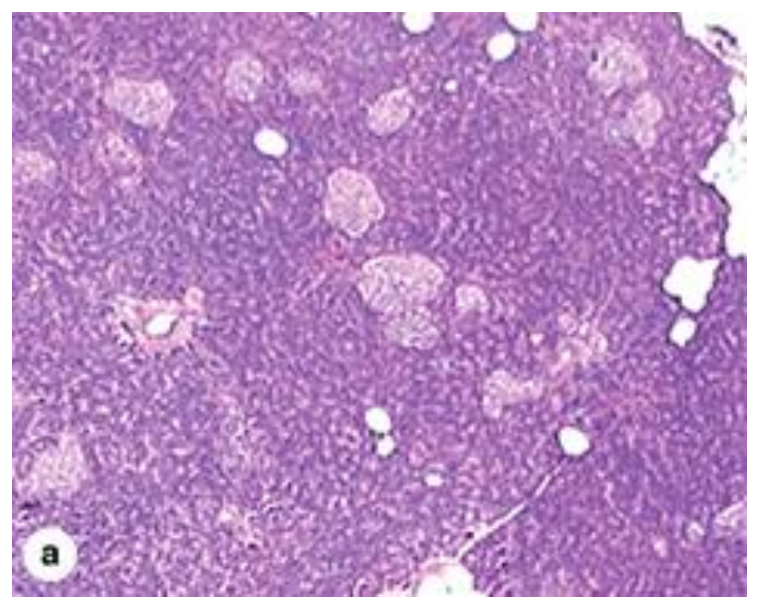

Gambar 1. Pulau Langerhans merupakan kelompok sel-sel endokrin berwarna pucat terpendam di dalam jaringan asinar eksokrin pankreas. Sumber: Mescher, 2010. ${ }^{2}$

Pulau-pulau Langerhans tersusun oleh beberapa jenis sel berbeda yang menghasilkan hormon berbeda pula. Sel alfa $(\alpha)$, sel beta $(\beta)$, sel delta $(\delta)$, dan sel polipeptida pankreas (PP) yang memroduksi glukagon, insulin, somatostatin dan polipeptida pankreatik secara berurut. Selsel ini saling memengaruhi melalui efek parakrin dalam pulau Langerhans. Hal ini menunjukkan adanya interaksi antar sel yang penting untuk mempertahankan fungsi normal pada tubuh manusia. ${ }^{5}$

Pada manusia, insulin promotor factor 1 (IPF-1) merupakan faktor transkripsi yang paling penting dalam hal diferensiasi spesifik dari sel beta pankreas dan induksi sekresi insulin. ${ }^{6}$

\section{SINTESIS INSULIN}

Manusia memiliki satu salinan gen insulin yang terletak pada kromosom 11 . Gen ini sudah diekspresikan di dalam sel beta pankreas dan terbentuk dari untaian DNA yang mencakup daerah pengode dan bukan pengode. Pada manusia gen insulin memiliki tiga ekson yang terpisah oleh dua intron. Ekson 1 dan 2 mengode bagian mRNA yang tidak mengalami translasi, ekson 2 mengode sinyal peptida $(\mathrm{P})$ dan rantai $\mathrm{B}$, ekson 2 dan 3 mengode peptida $\mathrm{C}$, dan ekson 3 mengode rantai A ditambah bagian mRNA yang tidak mengalami translasi. ${ }^{7-9}$

Preproinsulin merupakan produk translasi pertama dari gen insulin. Sinyal peptida diikat oleh partikel pengenal sinyal (signal recognition particle, SRP), kemudian melalui interaksi dengan reseptor SRP pada membran retikulum endoplasma (RE), terjadi penetrasi preproinsulin ke dalam lumen RE yang diikuti pembelahan proteolitik sinyal peptida dari preproinsulin menjadi proinsulin. Selanjutnya proinsulin akan mengalami lipatan yang sesuai untuk membentuk ikatan disulfida. Pada saat itu proinsulin yag telah dilipat dipindahkan ke aparatus Golgi dan dipisahkan untuk jalur konstitutif/pengaturan jalur keluarnya. Jalur konstitutif merupakan jalur yang digunakan sebagai jalan keluar yang pengaturannya tidak dilakukan oleh sekretagog. Selain itu, terdapat jalur lain dimana semua molekul proinsulinnya diurutkan, termasuk di dalamnya paket-paket prohormon yang sudah dikemas ke dalam granula sekretorik, selanjutnya akan terjadi proses eksositosis sebagai respon terhadap sekretagog. ${ }^{10}$

\section{SEKRESI INSULIN}

\section{Fase sekresi insulin}

Pelepasan insulin dari pulau-pulau Langerhans memerlukan pengaturan negatif untuk memastikan tingkat terendah melepaskan insulin dalam kondisi istirahat, serta pengaturan positif guna memfasilitasi respon kuat terhadap kondisi adanya peningkatan kadar glukosa darah. ${ }^{11}$ Insulin dilepaskan dalam bentuk bifasik yang terdiri dari fase pertama yang terjadi singkat (berlangsung sekitar 10 menit) dan diikuti oleh fase kedua yang berkelanjutan. Pada individu normal, laju sekresi insulin selama fase pertama dan kedua telah diperkirakan $1.600 \mathrm{pmol} / \mathrm{menit}$ dan 400 
pmol/menit. ${ }^{12}$ Fase pertama sekresi insulin melibatkan difusi kantung kecil dari granulgranul pada membran plasma. Kantungkantung tersebut mudah disekresi karena granul-granul tersebut sudah berada di dalam membran pada keadaan basal, dan pembongkaran isi granul-granul merupakan respon terhadap adanya nutrisi dan juga non-nutrisi sekretagog. Fase kedua sekresi insulin umumnya ditimbulkan oleh pengaruh nutrisi, dan melibatkan mobilisasi dari granul-granul intrasel ke tempat membran target soluble N-ethylmaleimide-sensitive factor attachment protein receptor (tSNARE) pada membran plasma untuk bisa memasuki bagian distalnya dan menjalani langkah-langkah fusi ekso-sitosis. ${ }^{11}$

\section{Sinyal sekresi insulin}

Homeostasis metabolisme energi sebagian besar dikendalikan oleh keseimbangan antara efek anabolik hormon insulin dan efek katabolik hormon glukagon. Sekresi insulin dari sel-sel beta pulau Langerhans diatur oleh sejumlah faktor, tetapi sinyal stimulasi yang dominan ialah peningkatan glukosa darah yang terjadi dengan mengonsumsi makanan yang mengandung karbohidrat. Selain glukosa yang merangsang terjadinya sekresi insulin pada sel beta secara langsung, hal ini dimungkinkan juga oleh fungsi potensial dari efektor lainnya seperti asam lemak bebas, asam amino, dan hormon inkretin (glucagon-like peptide-1, GLP-1). Kesemuanya ini memerlukan tingkat ambang glukosa tertentu (biasanya $6 \mathrm{mM}$ ) untuk dapat berefek.

Peningkatan glukosa darah menginduksi peningkatan metabolisme glukosa dalam sel beta, sehingga terjadi peningkatan produksi ATP melalui beberapa sumber: glikolisis, oksidasi glukosa mitokondria, dan pengangkutan aktif ekuivalen reduksi dari sitosol ke rantai transpor elektron mitokondria. Peningkatan yang dihasilkan pada rasio ATP/ADP menghambat ATPsensitive $K^{+}$channel sehingga mengakibatkan depolarisasi membran plasma, kemudian terjadi pembukaan voltage-gated $\mathrm{Ca}^{2+}$ channel diikuti dengan masuknya $\mathrm{Ca}^{2+}$ eks- trasel yang berfungsi untuk mengaktifkan eksositosis granul-granul (Gambar 2). ${ }^{13}$

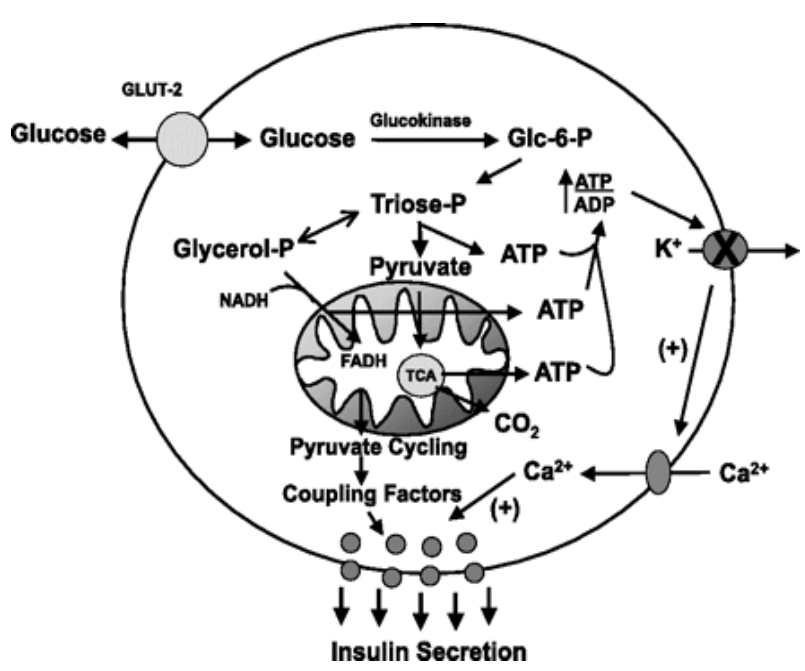

Gambar 2: Proses sekresi insulin. Sumber: Jensen et al, 2008. ${ }^{12}$

Pada Gambar 2 dapat dilihat bahwa glukosa akan diangkut dari dalam darah melewati membran sel masuk ke dalam sel; proses ini memerlukan senyawa pengangkut glukosa yaitu glucose transporter 2 (GLUT-2). Dalam keadaan fisiologik, transportasi transmembran dilakukan oleh GLUT-2 yang berfungsi sebagai pembawa glukosa dengan akses masuk ke dalam sel yang tak terbatas. Glukosa akan mengalami proses fosforilasi dan oksidatif oleh aktivasi glukokinase (mengubah glukosa menjadi glukosa-6 fosfat) dengan membebaskan molekul fosfat sehingga rasio ATP/ADP berubah, kemudian terjadi depolarisasi membran. ${ }^{14}$

\section{BAHASAN}

Sintesis dan sekresi insulin terjadi di dalam sel beta. Proses ini melibatkan beberapa komponen yang berperan dalam sintesis untuk menghasilkan insulin dan menyekresikannya ke luar sel. Pada keadaan tertentu komponen-komponen tersebut dapat mengalami disfungsi dan mengakibatkan terjadinya penyakit.

Masalah yang dapat terjadi pada sintesis insulin antara lain: 1) ketidak- 
mampuan pulau-pulau Langerhans untuk menghasilkan insulin dan 2) adanya stres pada RE yang melibatkan the un-folded protein response (UPR). Ketidak-mampuan pulau-pulau Langerhans untuk menghasilkan insulin mengakibatkan insulin yang keluar dari sel beta dan beredar di dalam darah kurang atau bahkan tidak ada. Ketidakmampuan tersebut terjadi karena proses autoimun sel beta yang ditemukan pada diabetes melitus tipe 1 (DMT1). Untuk mengatasi DMT1 ini harus diberikan preparat insulin agar dapat langsung bekerja di dalam darah. ${ }^{15,16}$

Adanya stres pada RE melibatkan UPR yang berperan dalam perkembangan selular agar sel dapat mempertahankan kapasitas dalam proses pelipatan protein. Stres yang terjadi pada RE akan mengakibatkan terjadinya mutasi pada pembelahan proinsulin yang berakibat kegagalan pelipatan insulin, sehingga sel tidak dapat menghasilkan jumlah insulin yang sesuai untuk mempertahankan homeostasis. Kegagalan sintesis insulin disini juga harus dibantu dengan pemberian preparat insulin. ${ }^{17,18}$

Disamping masalah sintesis, terdapat juga masalah sekresi. Penurunan sekresi insulin berkaitan dengan tiga fenomena berbeda: 1) desensitasi terhadap glukosa; 2) kelelahan (exhaustion) sel beta; dan 3) glucose toxicity.

Desensitasi terhadap glukosa juga dikenal sebagai resistensi insulin yang merupakan ketidaksanggupan insulin memberi efek biologik yang normal pada kadar gula darah tertentu. Selain akibat kurangnya reseptor insulin pada sel secara kuantitas, hal ini juga disebabkan gangguan pada pasca reseptor. Gangguan tersebut terdapat pada pembentukan (sintesis) dan juga translokasi dari suatu faktor yang penting bagi pemindahan glukosa dari darah kedalam sel untuk selanjutnya dimetabolisme yakni glucose transporter (GLUT). Pada awalnya resistensi insulin belum menyebabkan diabetes klinis. Sel beta pankreas masih dapat melakukan kom-pensasi, sehingga terjadi hiperinsulinemia.

Saat terjadi kelelahan sel beta pankreas maka akan timbul diabetes melitus klinis yang ditandai dengan kadar glukosa darah yang meningkat. Hasil penelitian menunjukkan adanya hubungan antara kadar glukosa darah puasa dengan kadar insulin puasa. Pada kadar glukosa puasa $80-140 \mathrm{mg} \%$ kadar insulin puasa meningkat tajam, akan tetapi jika kadar glukosa darah puasa melebihi $140 \mathrm{mg} \%$ secara berkepanjangan maka kadar insulin tidak mampu meningkat lebih tinggi lagi. Pada tahap ini mulai terjadi kelelahan sel beta yang menyebabkan fungsinya menurun.

Glucose toxicity berkaitan dengan peristiwa oksidatif yang lazim terjadi pada DMT2. Akibatnya kemampuan sel beta dalam fungsi sekresi insulin berkurang. Hal ini berhubungan dengan aktivasi gen uncoupling protein-2 (UCP-2) yang berasal dari produksi superoksida dalam mitokondria. Pada keadaan normal, aktivasi UCP-2 tidak terjadi sehingga ATP dalam jumlah yang cukup dapat dimanfaatkan bagi proses sekresi insulin. Pada keadaan hiperglikemia dan obesitas, terjadi ekpresi UCP-2 berlebihan dari sel beta. Peningkatan produksi superoksida pada mitokondria yang berpotensi mengaktivasi UCP-2 (yang memediasi pemborosan ATP menjadi bentuk panas) akan menyebabkan penurunan jumlah ATP, diikuti penurunan rasio ATP/ADP sehingga proses sekresi insulin menurun. ${ }^{19,20}$

Penelitian Thorens menunjukkan terjadinya kegagalan sekresi insulin bila GLUT2 berkurang $80 \%$ atau lebih. Berkurangnya GLUT-2 disebabkan karena berkurangnya enzim $N$-acetylglucosamine transferase $4 a$ yang mengode Mgat $4 a$ dan berfungsi dalam ekspresi GLUT-2. Defisiensi Mgat4a pada tikus menunjukkan ekspresi yang sangat rendah dari GLUT-2 pada permukaan sel-sel beta yang berakibat berkurangnya transpor glukosa. ${ }^{21}$

Untuk mempertahankan fungsi sel beta terdapat berbagai jenis obat yang dapat digunakan dengan tempat-tempat kerja yang berbeda (Gambar 3). Thiazolidinediones (TZDs) meningkatkan kepekaan insulin dengan bertindak sebagai ligan untuk reseptor hormon peroxisome proliferators 
activated reseptor- $\gamma(\mathrm{PPAR} \gamma)$ yang mengatur aktivitas transkripsi GLUT-4 sehingga meningkatkan uptake glukosa. PPAR $\gamma$ terutama ditemukan di jaringan adiposa, tetapi juga dapat ditemukan dalam sel beta pankreas, otot dan hati. ${ }^{22,23}$ Metformin termasuk golongan biguanid yang merupakan lini pertama untuk pengobatan DMT2. Metformin bertindak sebagai sensitizer insulin yang menghambat glukoneogenesis di hati, dan juga bermanfaat pada pasien DMT2 dengan kelebihan berat badan. Diduga efek metformin terjadi melalui peningkatan penggunaan glukosa oleh jaringan perifer yang dipengaruhi AMP acticated protein kinase (AMPK), yaitu regulator selular utama bagi metabolisme lipid dan glukosa. Aktivasi AMPK terhadap hepatosit akan mengurangi aktivitas Acetyl Co-
A karboksilase (ACC) dengan menginduksi oksidasi asam lemak dan menekan ekspresi ensim lipogenik. $^{24}$

\section{SIMPULAN}

Sel beta merupakan tempat terjadinya sintesis dan sekresi insulin. Awal sintesis berawal dari salinan gen pada kromosom 11 kemudian salinan tersebut akan mengalami proses yang akhirnya akan menghasilkan insulin yang dikemas di dalam granul-granul sekretorik.

Sekresi insulin diinduksi oleh kadar glukosa, kemudian terjadi reaksi di dalam sel. Perubahan rasio ATP/ADP akan memicu reaksi depolarisasi membran plasma, diikuti masuknya $\mathrm{Ca}^{2+}$ ekstrasel yang berfungsi mengaktifkan eksositosis.

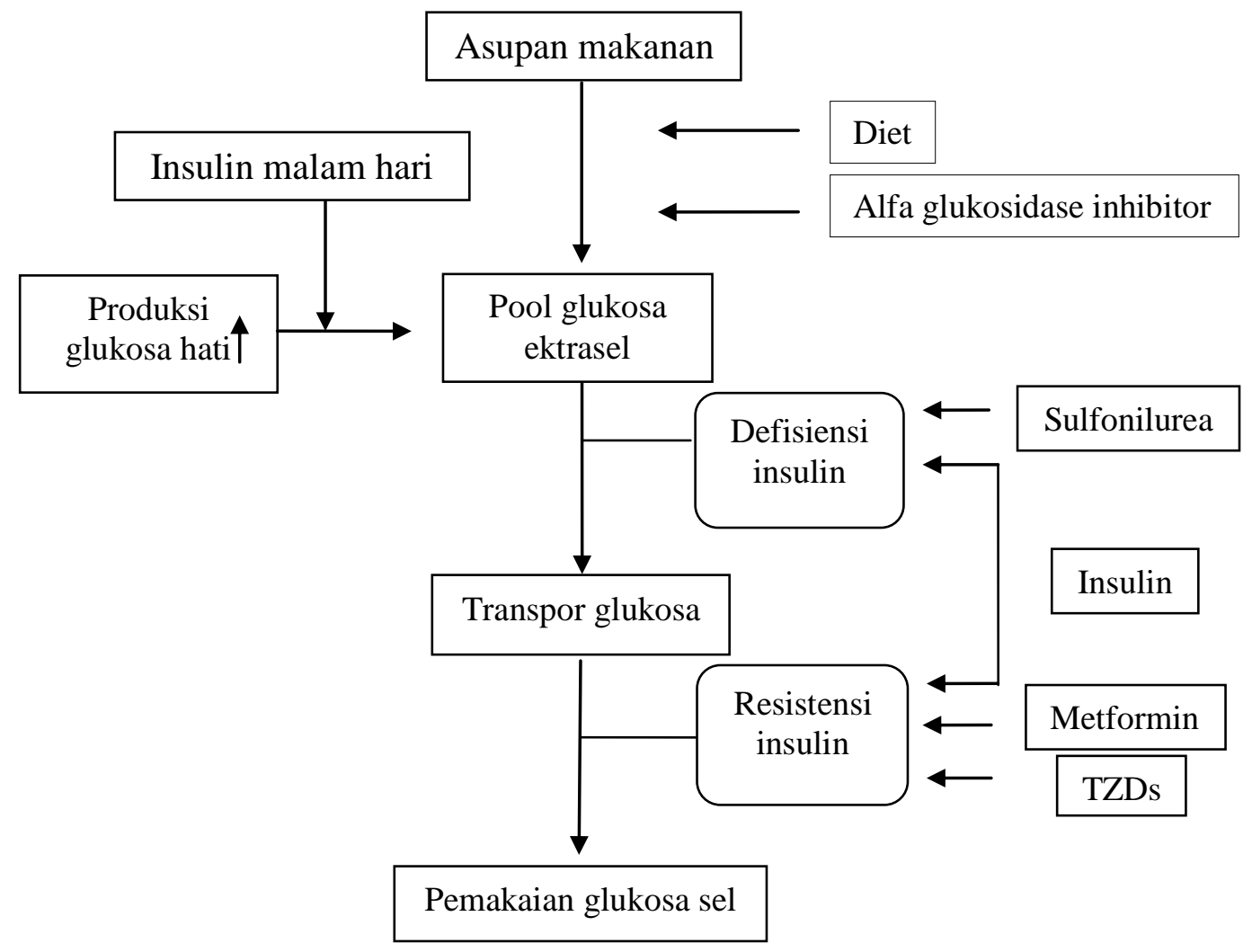

Gambar 3. Skema tentang sarana farmakologik dan titik kerja obat untuk pengendalian kadar glukosa darah. Sumber: Soegondo, 2009. ${ }^{21}$ 


\section{DAFTAR PUSTAKA}

1. Chanut F. A new tile in the biochemical puzzle of insulin biology [homepage on the Internet]. 2006 [update 2006 Jan 31; cited 2011 May 20]. Available from: http://www.plosbiology.org/article/info: doi/10.1371/journal.pbio.0040059.

2. Mescher AL. Junqueira's Basic Histology Text \& Atlas (Twelfth Edition). New York: McGraw-Hill, 2010.

3. Slomianka L. Blue histology [homepage on the Internet]. 2009 [update 2009 Aug 6; cited 2011 May 2011]. Available from: http://www.lab.anhb.uwa.edu.au/mb140 /CorePages/Epithelia/Epithel.htm.

4. Marks D, Marks A, Smith C. Biokimia Kedokteran Dasar. Jakarta: EGC, 2000; hal.92.

5. Hauge-Evans A, King A, Carmignac D, Richardson C, Robinson C. Low M, et al. Somatostatin secreted by islet $\delta$ cells fulfills multiple roles as a paracrine regulator of islet function [homepage on the Internet]. 2009 [updated 2009 May 14; cited 2011 April 28]. Available from: http://www. medscape.com/viewarticle/588893.

6. Skelin M, Rupnik M, Cencic A. Pancreatic beta cells lines and their applications in diabetes mellitus research [homepage on the Internet]. 2010 [updated 2010 May 17; cited 2011 May 15]. Available from: http://altweb.jhsph.edu/bin/e/z/ altex_2_10_skelin.pdf.

7. Hay C, Docherty K. Comparative analysis of insulin genes promoters: implications for diabetes research [homepage on the Internet]. 2007 [updated 2007 Feb 15; cited 2011 June 20]. Available from: http://www. medscape.com/viewarticle/551642.

8. Ganong W. Buku Ajar Fisiologi Kedokteran. Jakarta: EGC, 2008; p. 22.

9. Masahiro N, Nanjo $K$. Insulin gene mutations and diabetes [homepage on the Internet]. 2011 [updated $2011 \mathrm{Feb}$ 17; cited 2011 April 5]. Available from: http://onlinelibrary.wiley.com/doi/10.11 11/j.2040-1124.2011.00100.x/pdf.

10. Wang Z, Thurmond D. Mechanisms of biphasic insulin-granule exocytosis roles of the cytoskeleton, small, GTPases and SNARE proteins [homepage on the Internet]. 2009 [update 2009 Mar 18; cited 2011 April
14]. Available from: http://jcs.bio logists.org/cgi/content/short/122/7/893.

11. Rorsman P. Insulin secretion: function and therapy of pancreatic beta-cells in diabetes [serial online] 2005. The British Journal of Diabetes \& Vascular Disease [cited 2011 March 2011]; Vol 5(4):187-191. Available from: http://www.medscape.com/viewarticle/ 514155.

12. Jensen M, Joseph J, Ronnebaum S, Burgess S,Sherry A, Newgard C. Metabolic cycling in control of glucosestimulated insulin secretion [homepage on the Internet]. 2008 [updated 2008 Aug 19; cited 2011 April]. Available from:http://ajpendo.physiology.org/cont ent/295/6/E1287.full.

13. Thorens B. A toggle for type 2 diabetes? [homepage on the Internet]. 2006 [updated 2006 Apr 13; cited 2011 April 14]. Available from: http://www. nejm.org/doi/full/10.1056/NEJMcibr06 0422.

14. Khardori R, Type 1 diabetes mellitus [homepage on the Internet]. 2011 [updated 2011 May 31; cited 2011 April 14]. Available from: http:// emedicine.medscape.com/article/11773 9-overview\#a0104.

15. Lamb HW. Pediatric type 1 diabetes mellitus [homepage on the Internet]. 2010 [updated 2010 Sep 17; cited 2011 April 14]. Available from: http://emedicine.medscape.com/article/ 919999-overview.

16. Fonseca S, Burcin M, Gromada J, Urano F. Endoplasmic reticulum stress in beta cells and development of diabetes [homepage on the Internet]. 2009 [updated 2009 Aug 6; cited 2011 June 15]. Available from: http://www.ncbi.nlm.nih.gov/pmc/articl es/PMC2787771/.

17. Cunha D, Ladriere L, Ortis F, IgoilloEsteve M, Gurzov E, Lupi R, et al. Glucagon-like peptide-1 agonists protect pancreatic $\beta$-cells from lipotoxic endoplasmic reticulum stress through upregulation of Bip and JunB [homepage on the Internet]. 2009 [updated 2009 Aug 31; cited 2011 April 14]. Available from: http://diabetes.diabetesjournals.org/cont ent/58/12/2851.full?sid=7d1f7581. 
18. Manaf A. Thiazolidinediones: their role in the blood glucose and lipid control in prediabetes and diabetes [homepage on the Internet]. 2008 [updated 2008 Nov 12; cited 2011 April 14]. Available from: http://www.kalbe.co.id/print_ version.php? $\mathrm{mn}=$ news\&detail $=19825$.

19. Merentek E. Resistensi insulin pada diabetes melitus tipe 2 [homepage on the Internet]. 2006 [updated 2006; cited 2011 April 14]. Available from: http://www.kalbe.co.id/files/cdk/files/1 5_150_ResistensiInsulin.pdf.

20. Thorens B. A toggle for type 2 diabetes? [homepage on the Internet]. 2006 [cited 2006 Apr 13]. Available from: http://www.nejm.org/doi/full/10.1056/ NEJMcibr060422.

21. Soegondo S. Farmakoterapi pada pengendalian glikemia diabetes melitus tipe 2. In: Sudoyo AW, Setiyohadi B, Alwi I, Simadibrata M, Setiati S, editors. Buku Ajar Ilmu Penyakit
Dalam (Edisi Kelima). Jakarta: Internal Publishing; 2009.

22. McGrane D, Fisher M, McKay G. Drugs for diabetes: part 3 Thiazolidineones [homepage on the Internet]. 2011 [updated 2011 Mar 16; cited 2011 April 14]. Available from: http://www. medscape.com/viewarticle/738953.

23. Standl E. The importance of beta-cell management in type 2 diabetes [homepage on the Internet]. 2007 [updated 2007 Jun; cited 2011 April 14]. Available from: http://www.ncbi.nlm.nih.gov/pubmed/1 7594389.

24. McFarland M, Cripps R. Diabetes mellitus and increased risk of cancer: focus on metformin and the insulin analogs [homepage on the Internet]. 2010 [updated 2010 Nov 18; cited 2006 April 13]. Available from: http://www.medscape.com/viewarticle/ 731635 . 